\title{
Survival and growth of seedlings of 19 native tree and shrub species planted in degraded forest as part of a forest restoration project in Madagascar's highlands
}

Chris Birkinshaw, Mamisoa Andrianjafy' and Jean-Jacques Rasolofonirina'
Correspondence:

Chris Birkinshaw

Missouri Botanical Garden, BP 3391, Antananarivo 101

Phone: +261 202235344

E-mail: chris.birkinshaw@mobot-mg.org

\begin{abstract}
Percentage survival and mean percentage change in height were compared for 19 native tree and shrub species planted at Ankafobe Forest, a degraded fragment of highland forest, at ten months after planting. The species varied considerably in both, survival and growth. Best performers included Macaranga alnifolia (Euphorbiaceae), Harungana madagascariensis (Clusiaceae), Filicium decipiens (Sapindaceae) and Dodonaea madagascariensis (Sapindaceae). A comparison of survival between relatively short seedlings compared to relatively tall seedlings revealed no significant difference. This information will be used to increase the efficiency of forest restoration at this site.
\end{abstract}

\section{RÉSUMÉ}

Les projets de restauration forestière avec des espèces autochtones se rencontrent dans plusieurs sites à Madagascar. Cependant, il n'y a pas assez d'échange d'informations entre ces projets. Ces échanges sont pourtant importants car ils peuvent améliorer les méthodologies utilisées. Dans cet article les pourcentages de survie et les pourcentages moyens de croissance ont été comparés pour les 19 espèces d'arbres et d'arbustes autochtones plantées dans la Forêt d'Ankafobe, un bloc de forêt dégradée des hautes terres, à 10 mois après la mise en terre. Les plantules ont été produites localement à partir des graines collectées dans la Forêt d'Ankafobe. Le comportement des espèces varie considérablement en termes de survie et de croissance. Les espèces au meilleur comportement par rapport à ces deux variables comprennent Macaranga alnifolia, Harungana madagascariensis, Filicium decipiens et Dodonaea madagascariensis. Un fort taux de mortalité et une croissance lente ont été enregistrés pour Ixora sp., Trema orientalis et Elaeocarpus hildebrandtii. La comparaison de la survie entre les plantules relativement petites et les plantules relativement grandes de toutes les espèces confondues n'a révélé aucune différence significative. Cette information sera utilisée pour améliorer la réussite de la restauration de la forêt dans ce site. Néanmoins, une période de suivi plus long est important, tout comme l'identification des espèces propices à la restauration, c'est-à-dire celles qui peuvent améliorer la qualité du sol, créer de l'ombrage ou attirer les agents disséminateurs de graines.

\section{INTRODUCTION}

The historic and on-going loss of Madagascar's forest cover is well known (e.g. Sussman et al. 1994, Steininger and Harper 2003, Consiglio et al. 2006, Harper et al. 2008). It is possible to reduce or even reverse this trend by conserving the remaining native forest and restoring forest in areas where it has been lost. Active restoration of Madagascar's native forest is being practiced with increasing frequency as a means of improving connectivity between forest fragments, increasing the forest area, and increasing the area: perimeter-ratio of forest blocks (pers. obs.). In addition to the large scale and well known restoration projects such as the Ankeniheny-Mantadia-Zahamena Biodiversity Conservation and Restoration Corridor Carbon Project; the Fandriana-Marolambo Forest Landscape Restoration Project, and the restoration associated with QMM's mining activities; many existing protected areas (e.g. Réserve Naturelle Intégrale Betampona, Parc National (PN) Ranomafana, PN Masoala) and proposed protected areas (e.g. Ambalabe, Analalava, Mahabo, Sahamalaza, Tampina and Tampolo, (Sustainable Agriculture and Natural Resource Management Collaborative Research Support Program 2005, Birkinshaw et al. 2009) include more modest restoration or at least reforestation using native species activities around their fringes. The production and plantation of the young plants used by these projects requires significant investment yet there is little exchange of knowledge among the diverse practitioners in different parts of the country that could help improve methodologies employed and their resultant impact (but see Holloway (2000) and Pareliussen et al. (2006)).

Here we report on the comparative survival rate of several native tree and shrub species used in a forest restoration project in Madagascar's highlands. The results are also used to compare the survival of relatively short seedlings compared to relatively tall seedlings for all species combined, to test the importance of seedling size in restoration projects.

KEYWORDS: Humid forest, restoration, seedling survival, seedling growth.

MOTS CLEF : forêt humide, restauration, survie des plantules, croissance des plantules. 


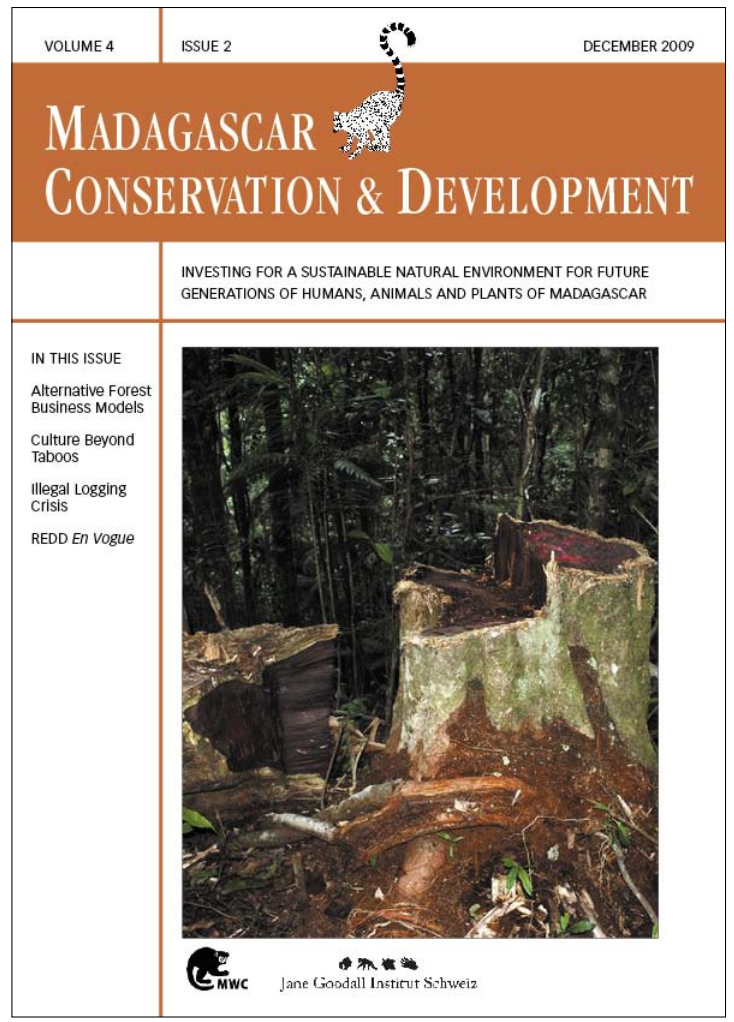

Madagascar Conservation \& Development is the journal of Madagascar Wildlife Conservation (MWC) and the Jane Goodall Institute (JGI Switzerland). It is produced in these institutions' own responsibility.

All the Issues and articles are freely available at http://www.mwc-info.net/en/services/journal.htm

Contact Journal MCD

info@journalmcd.net for general inquiries MCD funding@journalmcd.net for supporting the journal

Journal Madagascar Conservation \& Development Institute and Museum of Anthropology University of Zurich

Winterthurerstrasse 190

$\mathrm{CH}-8057$ Zurich, Switzerland

contact@mwc-info.net for general inquiries

Postfach 2701

CH-8021 Zürich, Switzerland

Logement 11, Cité Andohaniato

Antananarivo 101, Madagascar

info@janegoodall.ch for general inquiries JG

$2 \pi \approx$

Jane Goodall Institut Schweiz
Jane Goodall Institute Schweiz

Postfach 2807

8033 Zürich

switzerland 


\section{METHODS}

STUDY SITE. This research was conducted in the Ankafobe

Forest (E47 $11^{\circ}, \mathrm{S} 18^{\circ} 06^{\prime}$, elevation 1,475 m), a 33 ha forest fragment, located adjacent to Route Nationale (RN) 4 on the Tampoketsa of Ankazobe, $30 \mathrm{~km}$ northwest of Ankazobe, at Point Kilométrique (PK) 132, in Ankazobe Commune (Figure 1). The site is about $12 \mathrm{~km}$ west of Réserve Spéciale (RS) Ambohitantely, and can be considered an outlier of this large forest remnant because of its similar flora and proximity (pers. obs.). The Ankafobe Forest consists of fragments of humid evergreen forest (Moat and Smith 2007) located within a number of adjacent valleys. The forest is surrounded by anthropogenic grassland dominated by Trachypogon spicatus, Loudetia simplex and Aristida similis (Poaceae). Within the valleys, the forest is relatively sheltered from the strong winds that blow over the Tampoketsa's grasslands and stoke the wild fires that annually burn large areas within this commune (Ratsirarson and Goodman 2000). The former extent of forest on Madagascar's highlands remains unclear but certainly the remaining fragments were once larger as is testified by the occasional presence of trees surviving some distance from the current forest:grassland boundary. All easily accessible parts of the Ankafobe Forest, amounting to approximately $80 \%$ of its area, were commercially exploited for timber in 2002 and then around $30 \%$ of the remaining forest was burnt in 2003 when grassland fires penetrated the degraded vegetation (pers. obs.).

According to Cornet (1974), the climate at Ankafobe Forest can be classified as sub-humid with mists. Two distinct seasons occur; wet and hot between November and April, and dry and cool between May and October. Mean total average annual precipitation measured at RS Ambohitantely is $1,850 \mathrm{~mm}$, with $85 \%$ falling during the wet season. The highest average monthly temperature $\left(23.7^{\circ} \mathrm{C}\right)$ occurs in November, and the lowest $\left(13.5^{\circ} \mathrm{C}\right)$ in August. Fogs are particularly frequent in the dry and

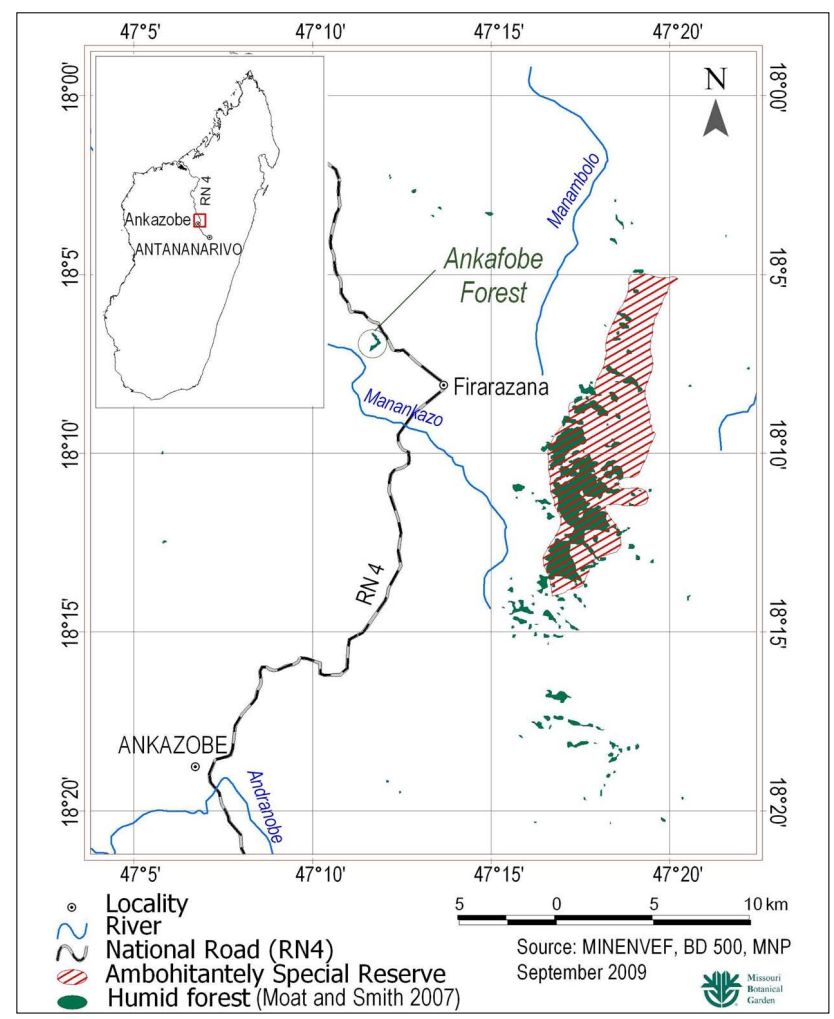

FIGURE 1. Location of study site. cool season (Ratsirarson and Goodman 2000, Pareliussen et al. 2006). The soil at Ankafobe Forest is an acid red laterite with high clay content (Ratsirarson and Goodman 2000).

Missouri Botanical Garden, in collaboration with a local, non-governmental association-Fikambanana Miaro ny Sohisika eto Tampoketsana (FMST), as well as the Cantonnement de I'Environnement, des Forêts et du Tourisme at Ankazobe, and the École Supérieure des Sciences Agronomiques, Département des Eaux et Forêts, Université d'Antananarivo, has been implementing since 2004 a program of activities aimed at studying, conserving, and expanding the Ankafobe Forest. This site is important because it contains much of the remaining population of the critically endangered tree schizolaena tampoketsana (Sarcolaenaceae - known locally as Sohisika) (Figure 2). We aim to promote the auto-regeneration of the forest at this site by preventing further burning using means of fire breaks and fire patrols. In addition, we are actively attempting to restore parts of the forest that have been burnt and transformed into thicket, shrub-or grassland and therefore have limited potential for auto-regeneration, by planting young plants of native tree and shrub species.

PLANTS USED FOR RESTORATION. In January 2008, a total

of 3,500 seedlings from 19 different native species of trees and shrubs were planted (Table 1) in parts of the Ankafobe Forest that had been burnt previously. There was no target list of species and the species used were those for which ripe seed samples could be collected from within the Ankafobe Forest during 2006 and 2007. The species sampled included both heliophiles and sciaphiles. The seedlings had been raised in the Projects' nursery, located at Firarazana (the village closest to Ankafobe Forest (Figure 1)). This outdoor nursery consists of shaded propagation beds constructed of local materials including logs to define the beds and bamboo culms to provide shade. Care was taken to collect ripe seeds. The seeds were cleaned by removing from fruit and washing, checked for obvious signs of predation such as small holes made by insects, and sown immediately into shaded seed beds filled with compost composed of one third well rotted manure, one third river sand and one third dark humus-rich soil collected from the top soil of the forest. When the seedlings had at least one real leaf they were transplanted into polyethylene pots containing compost and grown in shaded nursery beds until two months prior to planting out, when the shade was gradually removed to habituate the plants to full exposure to sunlight. When planted, the seedlings were between 8 to 20 months old, with height ranging from three centimeters to 48 centimeters. Given this very wide range of sizes, it was decided to assess the importance of seedling size on survival (but see Analysis).

PLANTING. The seedlings were planted on the upper slopes of a valley that previously had been forest but now, because of repeated burning over several decades, has been transformed to wooded grassland (as defined by White 1987). This vegetation differs from the surrounding anthropogenic grassland by the presence of occasional trees (remainders from the original forest) and the high abbundance of Pteridium aquilinum (Dennstaediaceae) within the herb layer. Planting was conducted early in the wet season because our previous experience has shown that seedling survival is better at this time than during the dry season. Each seedling was planted in a large hole (dimensions: $40 \mathrm{~cm} \times 40 \mathrm{~cm} \times 40 \mathrm{~cm}$ ) into which 


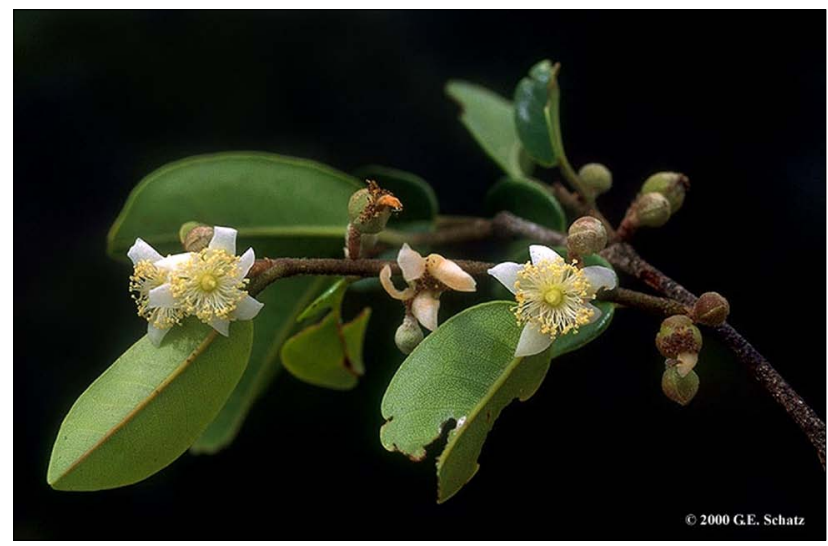

FIGURE 2. Flowering shoot of Schizolaena tampoketsana (photo: by kind permission of George E. Schatz).

about half a bucket of well-rotted manure had been mixed with the soil present. Plants were not watered after planting nor were they shaded or weeded because, although probably beneficial, funds were not available for these actions. Four to ten seedlings from each species were selected randomly for monitoring and marked with numbered stakes. The height of each seedling was measured at the time of planting and their survival and height measured again in November 2008, ten months after planting, at the end of the dry season during which period high mortality would be expected.

ANALYSIS. The performance of the various species was compared using the number of plants surviving after ten months, and the mean percentage change in height of living plants. In addition, while the number of seedlings studied for each species was too small to investigate the relationship between seedling height when planted and survival within species, we combined the data for all species to compare survival of relatively short seedlings and relatively tall seedlings. This was done by ranking the individuals of each species according to height when planted, and then grouping the shortest seedlings for each species into one group (mean height $=12.6 \mathrm{~cm}$ ), and the tallest seedlings for each species into another group (mean height $=19.2 \mathrm{~cm}$ ). The survivorship of the shortest plants was compared with the tallest plants using a $X^{2}$-test (following Campbell 1989).

\section{RESULTS AND DISCUSSION}

The percentage survival and mean percentage change in height for the 19 plant species are shown in Table 1. The species varied considerably in both survival and growth. These attributes will be related to both the physiology of the species and its adaptation to the planting environment. A combination of $100 \%$ survival and relatively rapid growth was observed for Macaranga alnifolia, Harungana madagascariensis, Filicium decipiens and Dodonaea madagascariensis. Low survival and slow growth or size reduction was observed for Ixora sp. (Rubiaceae), Trema orientalis (Celtidaceae) and Elaeocarpus hildebrandtii (Elaeocarpaceae). The poor performance of Trema orientalis (only one of four individuals survived and this became shorter because of death of the upper portion of the stem) was unexpected because this species is a succession pioneer that was expected to grow well in degraded habitats. However, Florentine (2008) also found better survival of later successional species than pioneer species in restoration experiments in

TABLE 1. Percentage survival and mean percentage change in height of survivors for 19 native species on Madagascar's highlands, ten months after planting; with comments on each species.

\begin{tabular}{|c|c|c|c|c|c|}
\hline Species & Family & $\mathrm{N}$ & $\%$ survival & $\begin{array}{l}\text { Mean \% change } \\
\text { in height of } \\
\text { survivors }\end{array}$ & Comments (mainly based on personal observation) \\
\hline Dodonaea madagascariensis & Sapindaceae & 10 & 100 & 98 & $\begin{array}{l}\text { Small shrub, leaves used to feed silkworms. Reported to be } \\
\text { an effective colonizer of burnt landscapes (Pareliuseen et al. } \\
\text { 2006) }\end{array}$ \\
\hline Harungana madagascariensis & Clusiaceae & 6 & 100 & 96 & Small tree, pioneer species, bird-dispersed \\
\hline Filicium decipiens & Sapindaceae & 10 & 100 & 75 & Medium tree, lemur-dispersed \\
\hline Macaranga alnifolia & Euphorbiaceae & 10 & 100 & 56 & Shrub or small tree, pioneer species \\
\hline Dracaena reflexa & Convallariaceae & 10 & 100 & 43 & Shrub, bird-dispersed \\
\hline Aphloia theiformis & Aphloiaceae & 7 & 100 & 24 & $\begin{array}{l}\text { Shrub, bird-dispersed, leaves used to make tisane, pioneer } \\
\text { species }\end{array}$ \\
\hline Ophiocolea sp. & Bignoniaceae & 10 & 100 & 16 & Shrub or small tree, lemur-dispersed \\
\hline Tambourissa purpurea & Monimiaceae & 10 & 100 & 6 & Small tree, lemur-dispersed \\
\hline Uapaca densifolia & Euphorbiaceae & 10 & 90 & 34 & $\begin{array}{l}\text { Small tree, lemur-dispersed, frequent species in native forest on } \\
\text { the highlands }\end{array}$ \\
\hline Schizolaena tampoketsana & Sarcolaenaceae & 10 & 90 & 29 & Medium tree, threatened species \\
\hline Macphersonia gracilis & Sapindaceae & 10 & 90 & 25 & Small tree, lemur-dispersed \\
\hline Eugenia sp. & Myrtaceae & 10 & 90 & 12 & Medium tree, lemur- and bird-dispersed \\
\hline Saldinia sp. & Rubiaceae & 10 & 80 & 52 & Shrub, bird-dispersed \\
\hline Canarium madagascariense & Burseraceae & 10 & 80 & 9 & Large tree, lemur-dispersed, key stone food species for lemurs \\
\hline Ravenea madagascariensis & Arecaceae & 10 & 70 & 37 & Medium palm, bird-dispersed \\
\hline Erythroxylum corymbosum & Erythroxylaceae & 10 & 60 & 27 & Small tree, bird-dispersed \\
\hline Ixora sp. & Rubiaceae & 10 & 40 & 2 & Shrub, bird-dispersed \\
\hline Trema orientalis & Celtidaceae & 4 & 25 & -68 & Shrub or small tree, pioneer species, bird-dispersed \\
\hline Elaeocarpus hildebrandtii & Elaeocarpaceae & 7 & 14 & 40 & Medium tree, lemur-dispersed \\
\hline
\end{tabular}


Australia. These results can only be considered as preliminary because other studies (e.g. Aronson et al. 2002, Florentine 2008) have shown that in comparisons of species' relative survival and growth, the best performers can change with time. No significant difference $\left(X^{2}=0.041, d f=1\right)$ was found between the survival of the shortest plants compared to the tallest plants for all species combined.

Pareliussen et al. (2006) studied the survival and growth rates of seedlings of five native tree and shrub species planted in grassland at various distances from forest within the RS Ambohitantely. Fifteen months after planting, survival of these species ranged from $40 \%$ to $51 \%$. The lower survival rate reported in this experiment compared to the current study may be due to its longer experimental period (15 months compared to ten months) and differences in experimental conditions. With respect to the latter, it is notable that Pareliussen et al. (2006) planted their seedlings in grassland whereas in the current study seedlings were planted within wooded grassland at the edge of the former forest where the environment might be expected to be closer to that within the forest. Pareliussen et al. (2006) found best survival close to the forest compared to relatively far from the forest. Pareliussen et al. (2006) also reported significant differences in survival and growth between the five species selected for their study. Two of their five study species (Dodonaea madagascariensis and Filicium decipiens) were also included in our study, and for these they reported relatively good survival and growth for $D$. madagascariensis but only moderate performance of $F$. decipiens.

\section{CONCLUSION}

The native species used in this experiment showed considerable variation in survival and growth rates. The preliminary results suggest that Macaranga alnifolia, Harungana madagascariensis, Filicium decipiens and Dodonaea madagascariensis perform well in terms of early survival and growth of seedlings and may be useful species in projects that aim to restore Madagascar highland forest. It is recommended that restoration projects, particularly those of large scale, should conduct trials to investigate survival and growth rates of candidate species rather then blindly investing resources in species that might have poor performance. However, it should also be recognized that survival and growth rates of native tree and shrub species is not the only relevant information for selecting species for restoration projects, and it is likely, that some species considered relatively poor performers on these criteria, may be included in restoration plans because of their importance as restoration facilitators acting, for example, to provide shade, to develop soils, to develop structural complexity or to attract seed dispersers. We found no significant difference in the survival of short versus tall seedlings suggesting that seedlings do not need to occupy tree nurseries for long periods before being planted at a restoration site.

\section{ACKNOWLEDGEMENTS}

We would like to thank the Cantonnement de l'Environnement, des Forêts et du Tourisme at Ankazobe, for supporting our restoration endeavours at Ankafobe; and the École Supérieure des Sciences Agronomiques, Département des Eaux et Forêts, Université d'Antananarivo, for providing us with access to their accommodation and tree nursery at Firarazana. We would also like to thank Dr. James Aronson for commenting on an earlier draft of this manuscript and for his support though the RNC Alliance, as well as three anonymous reviewers, and Christian Camara for translating the abstract into French.

\section{REFERENCES}

Aronson, J., Ovalle, C., Avendaño, J., Longeri, L. and Del Pozo, A. 2002. Agroforestry tree selection in Central Chile: Biological nitrogen fixation and early plant growth in six dryland species. Agroforestry Systems 56, 2: 155-166. (doi:10.1023/A:1021345318008)

Birkinshaw, C., Lowry II, P. P., Aronson, J., Lehavana, A., Reza, L., Andrianjafy, M. Rakotoarivony, F. and Rasolofomirino, J-J. 2009. RNC initiatives of the Missouri Botanical Garden. Accessed 30 July 2009 at <http://www. rncalliance.org>.

Campbell, R. C. 1989. Statistics for Biologists. Cambridge University Press, Cambridge.

Consiglio, T., Schatz, G. E., McPherson, G., Lowry II, P. P., Rabenantoandro, J., Rogers, Z. S., Rabevohitra, R. and Rabehevitra, D. 2006. Deforestation and plant diversity of Madagascar's littoral forests. Conservation Biology 20, 6: 1799-1803. (doi:10.1111/j.1523-1739.2006.00562.x)

Cornet, A. 1974. Essai de Cartographie Bioclimatique à Madagascar. Notice Explicative $\mathrm{N}^{\circ}$ 55. ORSTOM, Paris.

Florentine, S. K. 2008. Species persistence and natural recruitment after 14 years in a restoration planting on ex-rainforest land in north-east Queensland. Ecological Management and Restoration 9, 3: 217-224. (doi:10.1111/j.1442-8903.2008.00421.x)

Harper, G. J., Steininger, M. K., Tucker, C. J., Juhn, D. and Hawkins, F. 2008. Fifty years of deforestation and forest fragmentation in Madagascar. Environmental Conservation 34, 4: 325-333. (doi:10.1017/ S0376892907004262)

Holloway, L. 2000. Catalysing rainforest restoration in Madagascar. In: Diversity and Endemism in Madagascar. W. R. Lourenço and S. M. Goodman (eds.), pp 115-124. Mémoires de la Société de Biogéographie, Paris.

Moat, J. and Smith, P. 2007. Atlas of the Vegetation of Madagascar. Kew Publishing, Royal Botanic Gardens, Kew.

Ratsirarson, J. \& Goodman, S. M. 2000. Généralités sur la forêt d'Ambohitantely. In: Monographie de la Forêt d'Ambohitantely. J. Ratsirarson \& S. M. Goodman (eds.), pp 5-9. Recherches pour le Développement. Série Sciences Biologiques. Centre d'Information et de Documentation Scientifique et Technique N. 16, Antananarivo.

Pareliussen, I., Olsson, E. G. A. and Armbruster, W. S. 2006. Factors limiting the survival of native tree seedlings used in conservation efforts at the edges of forest fragments in upland Madagascar. Restoration Ecology 14, 2: 196-203. (doi:10.1111/j.1526-100X.2006.00121.x)

Sustainable Agriculture and Natural Resource Management Collaborative Research Support Program 2005. SANREM CRSP Workshop. Accessed 12 May 2009 <http://www.fishwild.vt.edu/sanrem/sanrem_home.htm>.

Sussman, R., Green, G. M. and Sussman, L. K. 1994. Satellite imagery, human ecology, anthropology, and deforestation in Madagascar. Human Ecology 22, 3: 333-354. (doi:10.1007/BF02168856)

White, F. 1983. The vegetation of Africa, a descriptive memoir to accompany the UNESCO/AETFAT/UNSO vegetation map of Africa. UNESCO, Natural Resources Research 20:1-356. 